\title{
Inuit Traditional Ecological Knowledge (TEK), Subsistence Hunting and Adaptation to Climate Change in the Canadian Arctic
}

\author{
Tristan Pearce, ${ }^{1}$ James Ford, ${ }^{2}$ Ashlee Cunsolo Willox ${ }^{3}$ and Barry Smit ${ }^{4}$
}

(Received 18 November 2013; accepted in revised form 7 August 2014)

\begin{abstract}
This paper examines the role of Inuit traditional ecological knowledge (TEK) in adaptation to climate change in the Canadian Arctic. It focuses on Inuit relationships with the Arctic environment, including hunting knowledge and land skills, and examines their roles in adaptation to biophysical changes that affect subsistence hunting. In several instances, TEK underpins competency in subsistence and adaptations to changing conditions, which includes flexibility with regard to seasonal cycles of hunting and resource use, hazard avoidance through detailed knowledge of the environment and understanding of ecosystem processes, and emergency preparedness, e.g., knowing what supplies to take when traveling and how to respond in emergency situations. Despite the documented importance of TEK in adaptation and in maintaining a level of competency in subsistence, the relationships between TEK and adaptation to climate change are not well defined in the scholarly literature. This paper aims to conceptualize the relationships between TEK and adaptation to climate change by drawing on case study research with Inuit in the Canadian Arctic. TEK is considered an element of adaptive capacity (or resilience) that is expressed as adaptation if TEK is drawn upon to adapt to changing conditions. This capacity depends on the development, accumulation, and transmission of TEK within and among generations.
\end{abstract}

Key words: adaptation; Inuit; Inuit Qaujimajatuqangit (IQ); resilience; traditional ecological knowledge (TEK); subsistence hunting; vulnerability

RÉSUMÉ. Cet article se penche sur le rôle des connaissances écologiques traditionnelles (CET) inuites en matière d'adaptation au changement climatique dans l'Arctique canadien. Il porte plus précisément sur les relations des Inuits avec l'environnement de l'Arctique, notamment en ce qui a trait à leurs connaissances de la chasse et à leurs pratiques ancestrales, puis il examine leur rôle en matière d'adaptation aux changements biophysiques qui exercent une influence sur la chasse de subsistance. Dans plusieurs cas, les CET servent de fondement aux aptitudes de survie et à l'adaptation aux conditions changeantes, ce qui implique de la souplesse vis-à-vis des cycles saisonniers de chasse et d'utilisation des ressources, l'évitement des dangers grâce à une connaissance approfondie de l'environnement et à la compréhension de la dynamique des écosystèmes et l'état de préparation en cas d'urgence, à savoir les vivres et le matériel dont ils doivent se doter lorsqu'ils sont en déplacement et la façon de réagir en situation d'urgence. Malgré l'importance documentée des CET sur l'adaptation et le maintien d'un niveau de compétence en vue de la subsistance, les liens entre les CET et l'adaptation au changement climatique ne sont pas bien définis dans les écrits érudits. Cet article cherche à conceptualiser les liens entre les CET et l'adaptation au changement climatique en s'appuyant sur une recherche d'étude de cas avec les Inuits de l'Arctique canadien. Les CET sont considérées comme un élément de la capacité adaptative (ou de la résilience) exprimée sous forme d'adaptation pourvu qu'elles soient employées pour favoriser l'adaptation aux conditions changeantes. Cette capacité dépend du développement, de l'accumulation et de la transmission des CET au sein des générations et entre elles.

Mots clés : adaptation; Inuit; Inuit Qaujimajatuqangit (IQ); résilience; connaissances écologiques traditionnelles (CET); chasse de subsistance; vulnérabilité

Traduit pour la revue Arctic par Nicole Giguère.

\section{INTRODUCTION}

Climate change is already being experienced in the Arctic with implications for ecological systems and human communities that depend on them for subsistence. The relationship between climate and Inuit ecological activities has been well documented, first by early Arctic anthropologists, including Boas (1888), Jenness (1917), and Stefansson

\footnotetext{
${ }^{1}$ Sustainability Research Centre, University of the Sunshine Coast, Locked Bag 4, Maroochydore DC, Queensland, 4558 Australia; Department of Geography, University of Guelph, Guelph, Ontario N1G 2W1, Canada; tpearce@usc.edu.au

${ }^{2}$ Department of Geography, McGill University, 805 Sherbrooke Street West, Montreal, Quebec H3A 0B9, Canada

${ }^{3}$ Community Health, Health Studies and Emergency Management, Cape Breton University, PO Box 5300, Sydney, Nova Scotia B1P 6L2, Canada

${ }^{4}$ Department of Geography, University of Guelph, Guelph, Ontario N1G 2W1, Canada

(C) The Arctic Institute of North America
} 
(1922), and more recently by Condon et al. (1995), Wenzel (2009), and Collings (2011). Other research has documented Inuit observations of climate change (Krupnik and Jolly, 2002; Fox, 2004) and examined how changes in the biophysical environment associated with anthropogenic climate change affect the lives and livelihoods of Inuit (Berkes and Jolly, 2002; Ford et al., 2006a, b, 2012; Pearce et al., 2010a; Prno et al., 2011; Andrachuk and Smit, 2012). In the subsistence hunting sector, recent climatic changes such as rising temperatures, changing sea ice dynamics, increased frequency and intensity of extreme weather events, and alterations to seasonal patterns have exacerbated hazards associated with travel on the land and ice, compromised trails to hunting grounds, and affected the health and availability of some fish and wildlife species important for subsistence (e.g., Berkes and Jolly, 2002; Pearce et al., 2010a; Ford et al., 2012). Potential benefits from climate change have also been noted, such as longer shipping seasons and longer ice-free periods for hunting by boat, but the majority of impacts are expected to be negative (Furgal and Prowse, 2008; Ford and Pearce, 2012). These changes, together with ongoing socioeconomic changes already being experienced by Inuit (e.g., living in permanent communities, colonial legacy, southern bans on the importation of seal and polar bear products) are affecting participation in subsistence hunting, food production, hunting safety and success, and the ability of Inuit to practice cultural and economic activities (Ford et al., 2008a; Tremblay et al., 2008; Wenzel, 2009; Collings, 2011; Cunsolo Willox et al., 2013).

Inuit have a long history of coping with and adapting to changing environmental conditions (Balikci, 1968; Krupnik, 1993; Freeman, 1996). However, the rapid changes associated with anthropogenic climate change, combined with the effects of socioeconomic changes, have made some historical adaptation efforts less plausible (e.g., shifting location to follow the migration of animals) and others more difficult (e.g., time constraints due to wage employment and formal education). Other adaptation efforts (e.g., focusing hunting on a reduced number of specific species) may actually increase vulnerability in the long term. In the context of contemporary Inuit society, key determinants of adaptation and entry points for policy to support Inuit-led adaptation to climate change have been identified (Gearheard et al., 2006; Laidler et al., 2009; Ford et al., 2010; Ford and Pearce, 2012). In particular, the ability of Inuit to cope with and adapt to biophysical changes that affect subsistence hunting continues to be associated with a profound knowledge of the Arctic ecosystem and land skills, referred to hereafter together as traditional ecological knowledge (TEK). This knowledge allows Inuit to make dynamic and flexible use of the environment and resources (Krupnik, 1993). Despite the recognized importance of TEK in maintaining a level of competency in subsistence and facilitating adaptation to a changing climate (e.g., Berkes and Jolly, 2002; Furgal and Sequin, 2006; Budreau and McBean, 2007; Ford et al., 2010), the relationship between TEK and adaptation is only beginning to emerge in contemporary climate change adaptation literature. This knowledge deficit perpetuates a focus in climate change adaptation research and policy on problem identification and description (e.g., risk/hazard/vulnerability/resilience assessments), rather than on evidence-based entry points to support adaptation through locally appropriate and culturally relevant strategies (Pearce et al., 2011a; Ford and Pearce, 2012).

This paper builds upon a body of scholarship on the role of TEK in adaptation to environmental change. Several studies conducted with Indigenous peoples in northern regions, including Inuit in the Canadian Arctic, suggest that TEK allows them to account for and deal with a large number of variations in the biophysical environment, including those associated with recent climate change (e.g., Peloquin and Berkes, 2009; Turner and Clifton, 2009; Pearce et al., 2011b; Ford and Pearce, 2012; Nakashima et al., 2012). The relationship between TEK and adaptation to environmental change is not unique to subsistence hunting, northern regions, or Inuit. It has also been documented among Indigenous peoples in the context of biodiversity conservation and environmental change globally (Gadjil et al., 1993; Berkes et al., 1995); among small-scale farmers in India (Rakshit and Bhowmick, 2012) and Jamaica (Beckford and Barker, 2007); Sami reindeer herders in northern Norway, Sweden, Finland, and Russia (Oskal et al., 2009); Indigenous peoples in the small Pacific island nation of Kiribati (Frankland et al., 2012), the Sahel (Nyong et al., 2007), and central Africa (Berrang-Ford et al., 2012); traditional and local forest users in the context of forest management (Parrotta and Trosper, 2012); and Aboriginal populations in Australia (Lewis, 1989; Gadji et al., 1993; Berkes et al., 1995) (Fig. 1). These claims have been made on the basis of the long histories that Indigenous peoples have of coping with and adapting to environmental changes, elements of which continue to be relevant today.

In this paper we conceptualize and examine the relationships among Inuit TEK, subsistence hunting, and adaptation to climate change, building on completed community-based vulnerability assessments and research on Inuit responses to adaptation policy, to examine the role of TEK in adapting to changes that affect subsistence hunting (Ford et al., 2010; Pearce et al., 2011a). We focus on Inuit relationships with the Arctic environment, including hunting knowledge and land skills, primarily at the individual scale among Inuit men, but we acknowledge that other aspects of Inuit knowledge (e.g., social values, environmental stewardship, community dynamics, beliefs) and gender dynamics also play interconnected roles in adaptation to changing conditions. We conceptualize TEK as an element of adaptive capacity (or resilience). TEK is expressed as adaptation if it is drawn upon to adapt to changing conditions. This depends on producing, accumulating, and transmitting TEK within and among generations. We illustrate these relationships using examples from climate change adaptation research conducted with Inuit across northern Canada, with particular reference to Ulukhaktok, an Inuit settlement in the Northwest Territories (NWT) where the relationships 


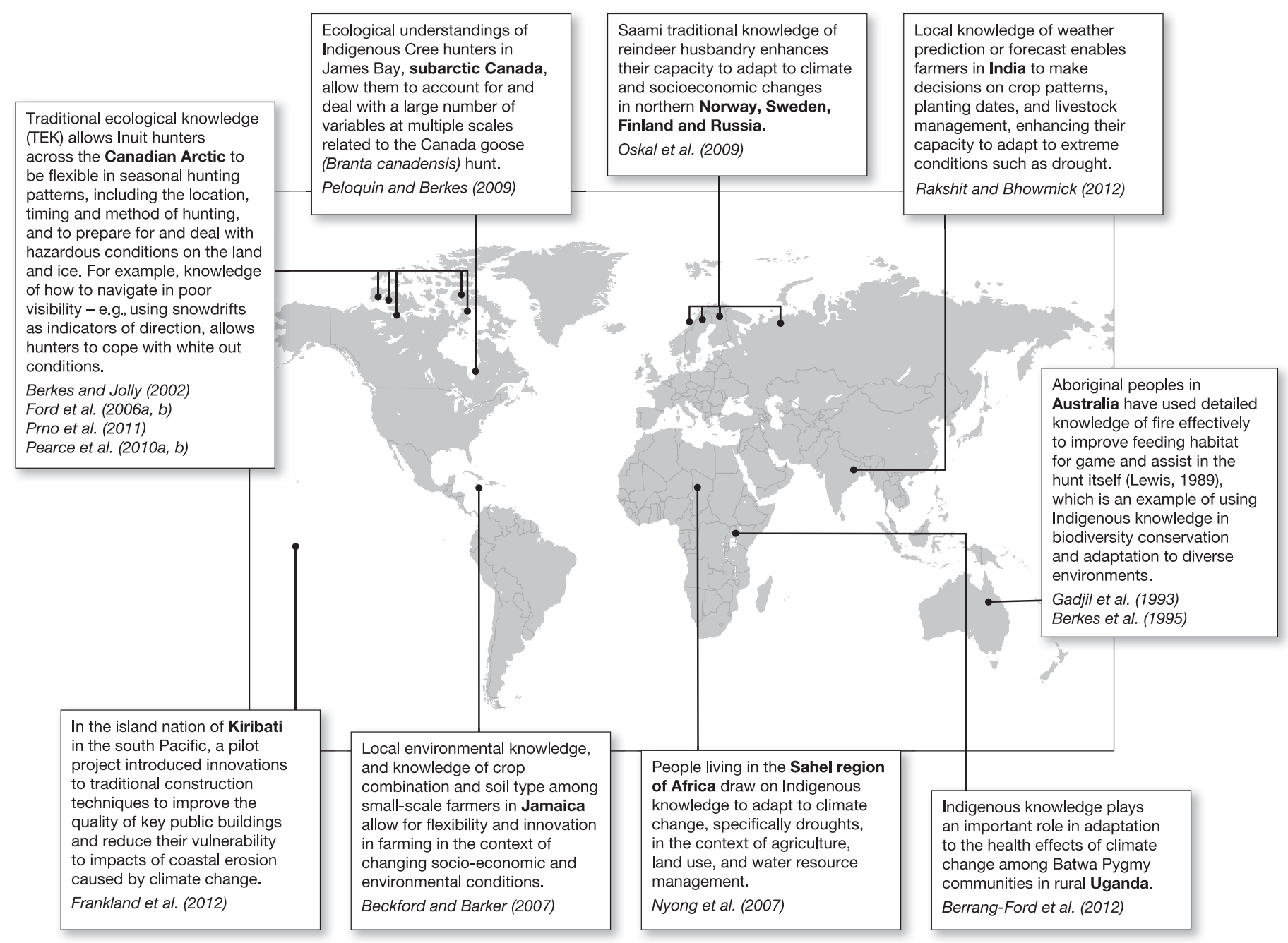

FIG. 1. Documented examples of applying Indigenous traditional ecological or local knowledge in adaptation to diverse and changing socioeconomic and environmental conditions, including climate change.

among TEK, subsistence hunting, and adaptation were specifically examined. At a broader level, the examples of Inuit TEK in adaptation and the need for culturally appropriate adaptation strategies have relevance for Indigenous peoples and subsistence-based communities in general, particularly those whose livelihoods are closely associated with traditional lifestyles based on natural resources.

\section{TEK AND ADAPTATION TO CLIMATE CHANGE}

\section{Defining Key Terms}

"Traditional knowledge" (TK) is broadly defined as a cumulative body of knowledge, practice, and values acquired through experience and observations on the land or from spiritual teachings and handed down from generation to generation (Cruikshank, 1998; Huntington, 1998; GNWT, 2005; Noongwook et al., 2007). "Traditional ecological knowledge" (TEK) has been used by various commentators as a synonym for TK and to refer specifically to those aspects of TK about the relationships of living beings (including humans) with one another and with their environment (Berkes et al., 1995; Wenzel, 1999). TK or TEK is built on personal experience and interaction with peers, including people from other communities (Huntington, 1998; Berkes, 1999) and passed on through stories, apprenticeship, and practice (Condon, 1996; Noongwook et al., 2007; Oskal et al., 2009). It can be understood as knowledge and skills that are fluid, dynamic, flexible, adaptable, and continually updated and revised in light of new observations and experiences, and it can incorporate new technologies alongside the traditional (Stevenson, 1996; Berkes, 1999; Usher, 2000; Takano, 2005; Bravo, 2009). For example, Inuit now travel and hunt more often by allterrain-vehicle (ATV), snow machine, and boat than by dog team and use high-powered rifles instead of bow-andarrow or spears, but the objective of their efforts remains unchanged and traditional ways of knowing continue to be relevant (Wenzel, 1991; Pearce et al., 2011b). TEK is interpreted broadly here to include the connections between the less tangible aspects of TEK (e.g., values and beliefs) 
and the practical skills and knowledge that govern Inuitenvironment interactions.

As noted earlier, TEK contributes to adaptive capacity (or resilience) in changing climatic conditions. Vulnerability generally refers to the susceptibility of a system (e.g., an individual or a community) to harm from a climate stimulus or stimuli; it involves both sensitivity to climate and adaptive capacity (Ford and Smit, 2004; Adger, 2006; Smit and Wandel, 2006). Exposure sensitivity is a joint property of the system's characteristics (e.g., livelihood, health, age, family status) and the characteristics of climate-related stimuli (e.g., magnitude, frequency, spatial dispersion, duration, speed of onset) (Cutter, 1996; Adger, 2006; Smit and Wandel, 2006). Adaptive capacity refers to the potential to adapt to climate change (including climate variability and extremes), to moderate potential damages, to take advantage of opportunities, or to cope with the consequences. Increased adaptive capacity therefore results in decreased vulnerability. We acknowledge a parallel body of scholarship that uses resilience to examine the human dimensions of climate change. Resilience focuses on examining the magnitude of climate change that can be absorbed before a system changes to a different state, as well as the capacity to self-organize and adapt to emerging circumstances (Adger, 2000; Berkes and Jolly, 2002; Chapin et al., 2006; Folke, 2006). Studies of adaptive capacity and resilience are closely related: both focus on how social-ecological systems experience and respond to stress, examine the capacity for adaptive action, characterize the multiple factors that influence how a system experiences and responds to stress, and engage in stakeholder-driven research. A key strength of vulnerability studies that use adaptive capacity as a concept is the focus on underlying socioeconomic and political drivers, which influence how an individual or community experiences change, as well as its capacity to adapt (Turner et al., 2003; Smit and Wandel, 2006; Ford et al., 2013).

\section{Conceptualization of TEK as Adaptive Capacity}

Adaptive capacity is conceptualized in vulnerability studies as a function of certain features of human systems that influence the propensity or ability to adapt (Adger, 2006; Smit and Wandel, 2006). These features vary among individuals and households, and over space and time, this variability translates into different capacities to adapt. Some documented elements or determinants of contemporary Inuit capacity to adapt to climate change exposures that affect subsistence include 1) TEK, 2) access to capital resources (e.g., hunting equipment, supplies, fuel), 3) emergency management capability, 4) flexibility of resource management regimes, 5) sharing networks (food and equipment), 6) availability of time, 7) technological options for adaptation (e.g., weather reports, GPS, satellite phone), and 8) health and well-being (Berkes and Jolly, 2002; Ford et al., 2010; Pearce et al., 2010a; Ford and Pearce, 2012). A common perspective on the relationships of adaptive capacity to its elements and

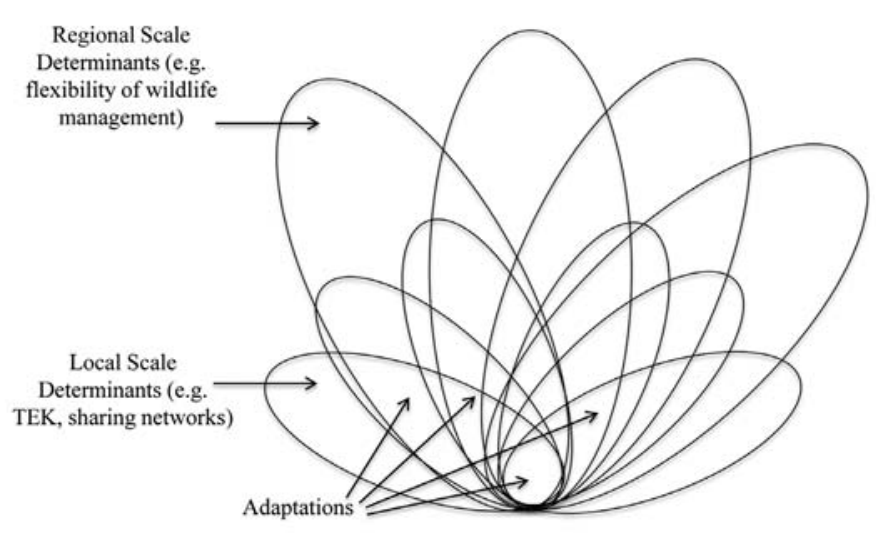

FIG. 2. Determinants of adaptive capacity operating across scales. Arrows point to intersections of regional- and local-scale determinants of adaptation (based on Ford et al., 2010; Pearce et al., 2010a).

the process of adaptation itself focuses on "the realization of adaptive capacity" (Brooks, 2003) or "manifestation of adaptive capacity" as adaptation (Smit and Wandel, 2006). Adaptive capacity can be described as a set of resources that represent an asset base from which adaptations can be made (Smit et al., 2000; Brooks, 2003; Vincent, 2007). The question is whether or not adaptive capacity will be drawn upon to bring about adaptation (Vincent, 2007).

Adaptations to changing climatic conditions in the Inuit subsistence sector are often synergies of several elements of adaptive capacity operating at different scales (Ford et al., 2010) (Fig. 2). In particular, TEK continues to play a pivotal role in the manifestation of many of these adaptive strategies. In some instances, TEK acts as an antecedent causal factor - that is, TEK builds other capacities. For example, adaptation to changing travel conditions on the land or ice or availability of wildlife may involve using alternative modes of transportation (e.g., a boat instead of a snow machine), hunting in unfamiliar locations, harvesting different species, or hunting at different times of the year. Here adaptation depends in part on the availability of capital resources (to purchase hunting equipment and supplies) or social capital (to borrow supplies) and time to participate in the hunt (e.g., constraints of wage employment). The feasibility and effectiveness of adaptation, however, hinges on having sufficient knowledge of the environment (TEK) to travel and hunt in unfamiliar locations and on flexibility of the wildlife management regimes that define the timing of seasonal hunts. In other cases, TEK acts as an effect modifier - the effectiveness of other factors of adaptive capacity is influenced by the strength of TEK. For example, switching the species hunted may be more effective for an experienced hunter than for one with less experience, which reflects their different levels of TEK.

\section{Examples of TEK in Adaptation}

Inuit in the Canadian Arctic use several adaptive responses to manage changing climatic conditions that 


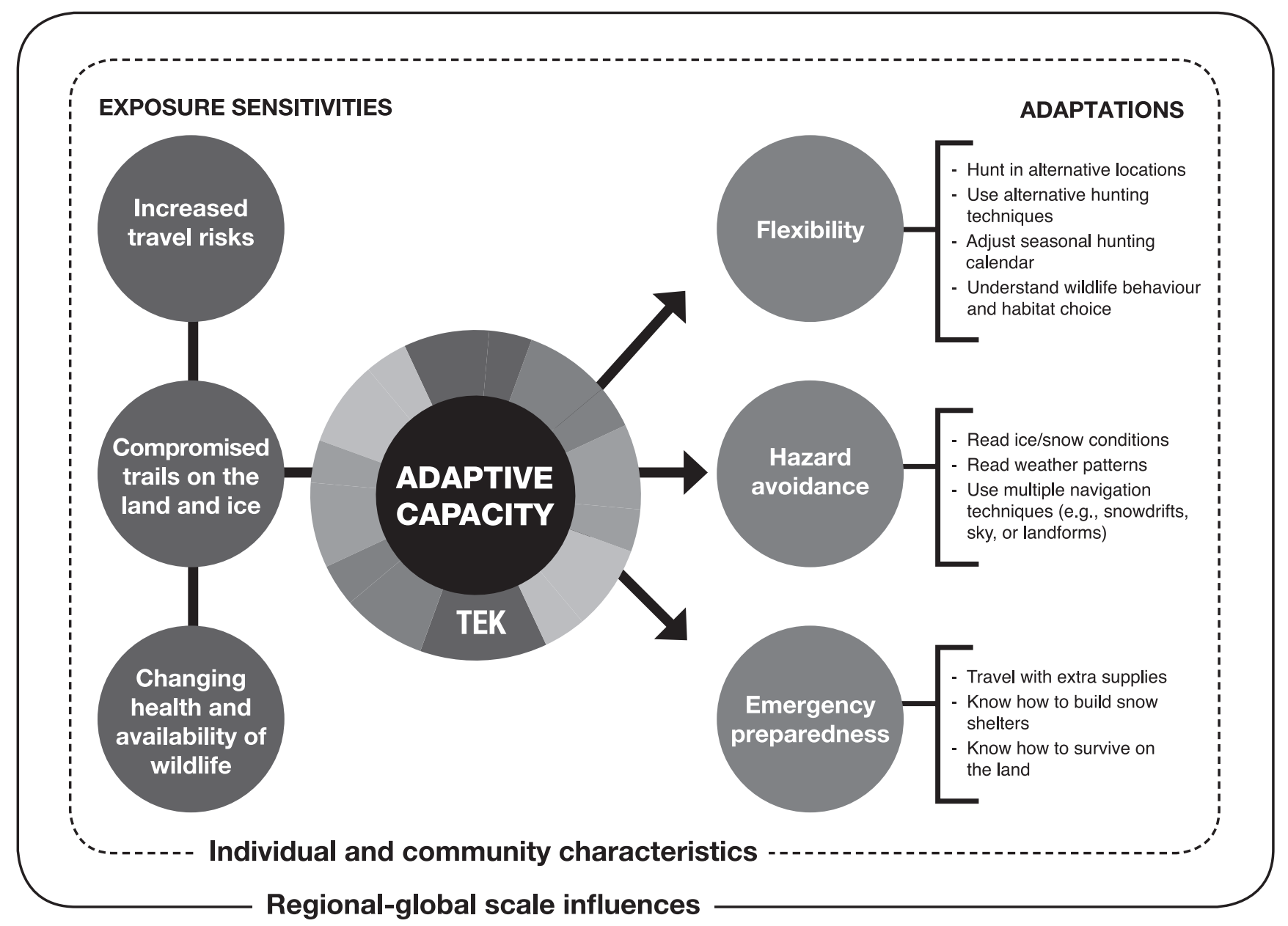

FIG. 3. Conceptual model of the relationships among TEK, subsistence hunting, and adaptation to climate change.

affect subsistence hunting. Documented responses include flexibility with regard to seasonal cycles of harvest and resource use; hazard avoidance made possible by detailed knowledge of the local environment and understanding of ecosystem processes; and emergency preparedness, which includes knowing what supplies to take when traveling and how to respond in emergency situations (Fig. 3). TEK plays an essential role in each of these adaptive responses. The figure simplifies the adaptation process by highlighting the role of TEK; however, as illustrated in Figure 2, multiple elements of adaptive capacity often work together in the adaptation process. These adaptive responses, grounded in TEK, are not unique to contemporary events. Flexibility, hazard avoidance, and emergency preparedness are skills inherent to Inuit subsistence hunting and have enabled Inuit to exploit the Arctic environment and resources for thousands of years (see Taylor, 1966; Balikci, 1968; Sabo, 1991). It is this collective social memory that Inuit draw on and modify today to cope with and adapt to current biophysical changes that affect subsistence hunting. The following examples from case study research conducted with Inuit across the Canadian Arctic illustrate the relationships among TEK, subsistence hunting, and adaptation (Fig. 4).
Flexibility: TEK is a dynamic, cumulative, living social memory from which adaptation actions can be derived to deal with both routine and novel events. Adaptability is a process of continual learning and readjustment: innovation and improvisation skills are gained through personal experience in the environment and are transmitted across generations to create a wealth of opportunities at any given time (Krupnik, 1993). Taken together, this cumulative body of knowledge of the environment and resources, TEK, allows hunters to be dynamic and flexible and continue hunting under changing climatic conditions (Ford et al., 2009).

Hunters are responding to changing ice and snow conditions by adjusting the timing of their seasonal hunting calendars, harvesting different species, using alternative travel routes and means of transportation (e.g., ATV or boat instead of snow machine in the spring), and sometimes by traveling and hunting in unfamiliar locations (e.g., Berkes and Jolly, 2002; Nickels et al., 2006; Ford et al., 2006b, 2008b; Pearce et al., 2010a; Prno et al., 2011). In their study of adaptation to climate change in Sachs Harbour, NWT, Berkes and Jolly (2002) suggest that flexibility, rooted in TEK, of the seasonal cycles of harvest and resource use provides the social-ecological resilience needed to cope with increased variability and unpredictability and adapt 


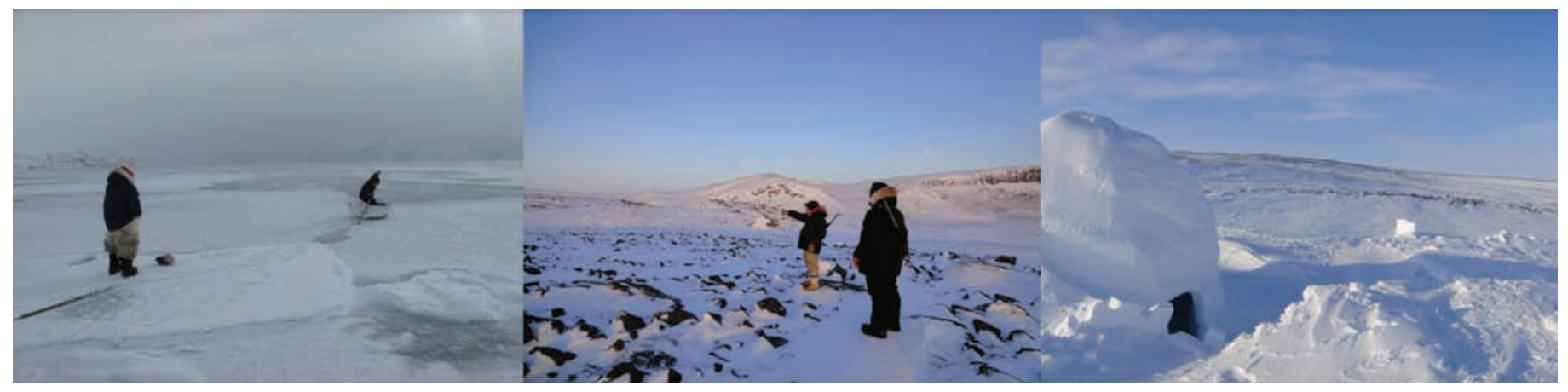

FIG. 4. Photographs of Inuit in the Canadian Arctic illustrating responses to changing climatic conditions that affect subsistence. (Left): Flexibility - Iqaluit hunters improvise, using boats to maintain access to seal hunting areas in late fall. (Centre): Hazard avoidance - Ulukhaktok hunters make extra efforts to read weather and ice conditions before and during travel. (Right): Emergency preparedness - Knowledge of how to build an emergency snow house enables hunters to wait out storm events.

to change. In this case, TEK acts as an antecedent causal factor. In some instances, adaptation involves being sensitive to critical signs in the environment and knowing how to respond. Knowledge of animal behavior enables hunters to adapt to changing animal numbers and locations, while knowledge of the land underpins their ability to do this. When one species of wildlife is less abundant, Inuit shift to hunting another species, an adaptation that depends on the diversity of wildlife available and on the hunter's knowledge of animal behavior and new hunting locations.

For example, the Peary caribou (Rangifer tarandus pearyi) population on Victoria Island, in the Inuvialuit Settlement Region (ISR), a primary source of meat for many Inuit in Ulukhaktok, declined dramatically beginning in the late 1970s (Collings, 1997). This decline is thought to have been due in part to an increase in the frequency of freezethaw events, which create ice layers in the snow pack and hinder the ability of caribou to travel and forage for food (Barry et al., 2007). Around the same time as caribou populations declined, muskox (Ovibos moschatus) populations increased, and Inuit have been able to substitute muskox for some of the lost caribou meat (Pearce and Smit, 2013). This change was feasible for many hunters because the general knowledge and skills important for hunting caribou were transferable to hunting muskox. In this instance, TEK acts as an effect modifier in that successful adaptation depends on the hunter's level of knowledge and skills for basic hunting: a more experienced hunter is able to switch species hunted more easily than a less experienced hunter.

Inuit are also demonstrating flexibility in modes of travel, locations, and techniques for hunting. Across the Canadian Arctic, boats are becoming increasingly important to Inuit hunters for adapting to changing sea ice conditions (earlier breakup, later freeze-up, and unstable ice conditions) and are being used in spring and autumn to access hunting areas that were previously accessible only by crossing the sea ice, either on foot or using a dog team or snowmobile (Ford et al., 2006a, b; Pearce et al., 2010a). For example, because of earlier sea ice breakup and thinner, less stable ice conditions, Ulukhaktok hunters are traveling on the ocean by boat to hunt king eider ducks (Somateria spectabilis) more often in the spring. Hunting ducks from a boat, however, is more difficult than hunting them from the land or ice. Thus, new skills are being developed to access duck hunting grounds (e.g., launching boats from the floe edge) and to shoot and retrieve ducks successfully (Pearce et al., 2010a). In this case, TEK acts as both an antecedent causal factor and an effect modifier: adaptation depends on knowing enough about the sea ice to launch a boat from the floe edge and understanding the behavior of ducks sufficiently to know how to hunt them from a boat. Again, experienced marine hunters are better equipped to make these behavioral adjustments than less experienced hunters.

Hazard Avoidance: The hunters' ability to cope with and adapt to changing conditions increasingly involves taking extra efforts to read weather and ice conditions before and during travel (Pearce et al., 2010a). Before traveling on the land or ice, experienced hunters consult with Elders and closely observe the weather, clouds and wind, looking for subtle warning signs that are precursors of hazardous conditions (Gearheard et al., 2006, 2010). Inuit are astute and highly skilled observers of sea ice and weather conditions and draw on past knowledge, lessons, and experiences traveling on the ice to determine when and where it is safe to travel (Nelson, 1969; Wenzel, 1991; Aporta, 2002; Krupnik, 2002; Laidler and Elee, 2008; Laidler and Ikkumaq, 2008; Laidler et al., 2009). Additionally, many Inuit hunters now regularly consult satellite imagery of the sea ice and weather forecasts before traveling (Pearce et al., 2010a). Together with TEK, this information provides Inuit with a knowledge base from which to make judgements about when and where to travel.

New technologies are playing a crucial role in hazard avoidance and facilitating adaptation to changing conditions. Several scholars have documented the use of Global Positioning Systems (GPS) and other technologies such as satellite phones, Very High Frequency (VHF) radios, and distress beacons as adaptive strategies for travel conditions that are no longer easily predicted using traditional methods only (e.g., Ford et al., 2006a; Laidler et al., 2009; Pearce et al., 2010a; Aporta, 2011). These modern technologies are being adopted in the context of decreasing time available 
for hunting because hunters participate in the wage economy (e.g., some hunters can travel only on weekends); a reduction in land-based skills, especially among younger generations (see Aporta and Higgs, 2005; Ford et al., 2006a; Pearce et al., 2010a, 2011b); the requirements of hunting with snow machines and motorized boats; and the perception of safety that many of these devices provide. However, the uptake of new technologies (and sometimes neglect of TEK) can also create new exposure sensitivities and exacerbate existing ones.

Research in Igloolik and Ulukhaktok has documented more risk-taking behavior among hunters associated with technological developments. The use of VHF radios and GPS and the functioning of a community search and rescue group, which provide a safety net if problems are encountered, have resulted in overconfidence and less caution (Ford et al., 2008b). Some hunters are now hunting in conditions that traditionally would have been considered dangerous, risking damage to their equipment and exposing themselves to potential injury or even loss of life. GPS provides hunters with an alternative navigation method and can be useful in poor visibility and emergency situations, but it also enables individuals with limited knowledge about navigation and about the environment to travel (Aporta and Higgs, 2005). Consequently, young and inexperienced hunters can now travel alone or in the absence of more experienced hunters to locations where they would not have gone previously. Even travel along well-used routes that are perceived as safe can be problematic if the GPS fails and traditional navigation skills are not known (Ford et al., 2006a).

The benefits of GPS, VHF radios, and weather and sea ice reports are noted, but as documented by Pearce et al. (2011b) in Ulukhaktok, Inuit hunters rely on a combination of traditional navigation skills and new technologies. Weather and sea ice reports have become valued tools when TEK of weather and ice is challenged by the rapid pace of climate change; however, experienced hunters stress that traditional navigation skills continue to be important for safe travel (Ford et al., 2006a). In particular, when new technologies fail (e.g., a weather or sea ice report is incorrect or the GPS battery dies), hunters must depend on traditional knowledge of the environment and land skills (Pearce et al., 2011b). Experienced hunters navigate on the land by remembering landforms and on the sea ice using knowledge of the prevailing wind and snowdrifts. This knowledge is being continually updated and revised in light of changing climatic conditions, which requires active engagement in subsistence hunting and the transmission of this knowledge to younger generations. In a case study of TEK transmission among hunters in Ulukhaktok, $93 \%$ of hunters $18-34$ years of age had learned to travel by remembering landforms $(100 \%$ transmission rate among hunters 35-49 years of age and Elders), and experienced hunters continue to teach young hunters how to navigate using landforms despite the availability of GPS (Pearce et al., 2011b). In reference to hazard avoidance, TEK acts as an effect modifier, in that hunters who are knowledgeable of a combination of traditional and new technologies for weather forecasting and navigation are better equipped to deal with changing conditions than hunters who rely solely on new technologies.

Emergency Preparedness: Prior to moving into permanent settlements, Inuit followed the seasonal migrations of wildlife; subsistence hunting was synonymous with living. Today, Inuit subsistence hunting is constrained by living in permanent settlements, which reduces mobility; wage employment, which restricts time; the rising cost of equipment, supplies, and fuel, which limits how far hunters can travel; the advent of new technologies that enable hunters to travel farther and faster; and lifestyle changes that cause hunters to make more expedient day trips near the settlement. The nature of subsistence hunting has changed, and so have methods of emergency preparedness.

Inuit hunters increasingly anticipate the possibility of encountering hazards when traveling and hunting on the land and ice. They are aware of the limitations of mechanized equipment (which can break down) and are taking extra precautions to avoid and be prepared to cope with emerging risks (Ford et al., 2006a; Pearce et al., 2010a). Hunters are packing extra supplies (such as gas, naphtha fuel for heat and cooking, food, a tent even for day trips, ammunition, and extra warm clothing), and some hunters now travel with satellite phones or VHF radios to maintain communication with the settlement. These extra precautions increase the financial cost of hunting and may affect participation in hunting and the frequency of hunting trips. Further empirical examination is needed to substantiate this hypothesis. An experienced hunter in Ulukhaktok explains his key rule when packing his aaliak (sled) (W. Joss, pers. comm. 2013). He calls it the "Rule of Threes," which refers to packing three of every key supply. This means three parkas (wear one, pack two), three stoves, three naphtha bottles, three rifles, three knives, three pairs of mitts, three pairs of boots, three times the necessary amount of gas and naphtha (either carried or cached on the land), and so on:

\begin{abstract}
It's not like long ago, sometimes you have to travel far to find anything; sometimes you see nothing. I'm not getting stuck out there without any gas. I have lots of gas stored all over and cabins. I can stay out there [on the land] long, no problem.... If your zipper [in your parka] breaks, then what? I've got three parkas and an extra .22 [rifle] on my skidoo.
\end{abstract}

(W. Joss, 2013)

His philosophy is that your travel partner will likely need one item at some point, the item you are wearing could fail, and then you have a third as a safety reserve. You may need to travel farther than you anticipated to find animals, which requires more gas for your ATV, boat, or snow machine, and naphtha for heating and cooking. The Rule of Threes gives the hunter confidence that he can cope with unpredictable conditions and events that may unfold. Additionally, several hunters in Ulukhaktok are anticipating having 
to travel farther to hunt muskox and caribou and are constructing small (approximately $8 \mathrm{ft} \times 8 \mathrm{ft}$ ) plywood cabins equipped with stoves, gas caches, and basic provisions at strategic locations on the land. Having well-equipped cabins and gas stored on the land allows hunters to travel with lighter sleds or boats, access hunting areas that require multi-day travel, and take refuge in poor weather conditions. A tent serves a similar purpose, but cabins and fuel caches allow for lighter-weight travel, which means using less fuel and having greater capacity to carry meat back to the settlement. Moreover, cabins provide emergency shelter in extreme conditions when strong winds and poor visibility (niptiaktuk) make it too difficult to set up a tent or construct an igloo.

Despite even the most careful preparation, however, hunters sometimes encounter challenging or unexpected conditions when traveling, such as blizzards and other extreme storm events and unusual ice conditions. Hunters react to extreme conditions by drawing on their extensive TEK and the resources available to them to cope with the disturbance (Pearce et al., 2010a, b; Heyes, 2011). Pat Ekpakohak, an experienced hunter and Elder of Ulukhaktok, said that his pre-hunting planning and cold-weather survival knowledge saved his life when his snow machine plunged through the rapidly thinning sea ice in white-out conditions. Because he had quick access to his knife, he was able to cut the rope hitch to his snow machine and save his aaliak, while watching his snow machine sink. He was prepared with VHF radio and a tent, which he set up while suffering the onset of hyperthermia, and was able to radio relatives in the settlement for help (P. Ekpakohak, pers. comm. 2012). The Arctic sea ice is an inherently dangerous environment and one must have basic knowledge of how to travel safely (e.g., be prepared for unpredictable conditions or an accident) to participate in subsistence. As sea ice and weather conditions become more unpredictable and trail conditions deteriorate, emergency preparedness skills become even more important to deal with unexpected hazards.

In other instances, having knowledge of multiple navigation or way-finding techniques, including navigation using snowdrifts, celestial navigation, and remembering landforms, can help hunters to find refuge and set up camp or travel back to the settlement. An experienced Inuit hunter who is faced with extreme weather conditions while traveling on the sea ice can also draw on this knowledge to construct an emergency snow house (igloo or nalaaqtaq) to wait out the storm, provided he had the foresight to travel with a snow knife (Pearce et al., 2011b; Ford et al., 2013). Careful preparation before hunting is key to coping with adverse conditions; it includes a strong understanding of the local environment and land skills, forethought and planning (e.g., caching fuel, building cabins, packing extra supplies), and knowledge of how to survive in the Arctic (e.g., knowledge of cold weather survival and treatment of hypothermia). Emergency preparedness knowledge and skills are inherent in Inuit hunting culture and are being updated and modified in light of new technologies, resources, and information to meet the challenges of a rapidly changing climate.

\section{TEK TRANSMISSION}

The ability of an individual to draw on TEK to adapt to changing conditions depends on whether (and to what extent) TEK has been transmitted. In this context, transmission refers to the process of transferring a cultural item, such as a skill or locally specific piece of knowledge, from individuals to others through participation and experience in an environment, and transmission success depends on the level of mastery of a particular item (Ohmagari and Berkes, 1997; Ingold, 2000; Pearce et al., 2011b). Traditionally, TEK was generated and transmitted among Inuit through hands-on education on the land and by listening to and learning from Elders and other experienced individuals (Wenzel, 1987; Condon, 1996; Barnhardt and Kawagley, 2005; Takano, 2005; Pearce et al., 2011b). In their study of TEK transmission among Inuit men in Ulukhaktok, Pearce et al. (2011b) confirm that the traditional modes of TEK transmission, observation, and apprenticeship continue to function today, albeit with varying degrees of success across the population. Some knowledge and skills have been lost, some are being transmitted incompletely or only at elementary levels, and others are new knowledge and skills (e.g., how to navigate using a GPS, read a weather report, or fix a snowmobile) that the older generation did not possess, but which are currently being widely adopted (Berkes and Jolly, 2002; Ford et al., 2006b; Pearce et al., 2011b).

The loss and weakening of TEK among some younger Inuit are linked to a gradual disengagement of younger generations from the land and subsistence activities, beginning with the settlement of Inuit in communities starting in the late 1950s and accelerating over subsequent generations. Unlike their parents and grandparents, young Inuit today are generally spending less time involved in subsistence activities beyond organized land-camps and occasional hunting trips. As a result, some have fewer opportunities to learn the knowledge and skills necessary for safe and successful travel and hunting under changing climatic conditions.

Inuit leaders and northern representatives acknowledge the need for institutional support to assist in strengthening the transmission of TEK among younger Inuit, particularly among marginalized community members. Institutional programming clearly does not replace traditional methods of TEK transmission through observation and apprenticeship; it does, however, provide some Inuit youth, many of whom would otherwise not have the opportunity, a chance to participate in subsistence and gain exposure to skills, teachers, and mentors. Having such knowledge and skills allows young Inuit to engage in productive activities that continue to have economic and social value. 
In recognition of the socioeconomic and cultural importance of subsistence hunting for Inuit, efforts to support TEK transmission under changing conditions should be complemented by efforts to alleviate longstanding issues that negatively affect subsistence. The sustainability of subsistence depends in part on how non-Inuit perceive the vulnerability of Arctic wildlife to climate change and Inuit hunting techniques (e.g., modernization of hunting) (Wenzel, 2009). Top-down wildlife management regimes and non-Inuit political decisions, including the ban on the importation of seal and polar bear products to the United States and the European Union, have had devastating effects on Inuit subsistence (Wenzel, 1987, 2009). The southern anti-sealing and animal rights movement in the 1980s led to the eventual demise of the Inuit commercial seal hunt and negatively affected the ability of future generation Inuit to exploit a key traditional resource (Wenzel, 1987). A strong economic basis promotes participation in subsistence hunting and facilitates opportunities for the generation and transmission of TEK.

\section{CONCLUSIONS}

The global climate is undergoing rapid change, with implications for lives and livelihoods of people worldwide. Indigenous populations around the world have been identified as particularly vulnerable because they live in regions undergoing rapid change, continue to rely on resourcebased livelihoods, and in many instances have experienced colonization and cultural change, the legacies of which continue to exacerbate current challenges (Berrang-Ford et al., 2012; Nakashima et al., 2012). The Arctic is at the forefront of these changes, and Inuit vulnerabilities to climate change are well documented, including impacts on subsistence hunting, fishing, trapping, cultural activities, and health and well-being. Finding ways to adapt that meet local needs and fit with cultural norms is therefore a key challenge facing Inuit populations in Canada, as well as other Indigenous populations globally. Fortunately, Indigenous peoples have long histories of adapting to changes in society and environment, and their accumulated knowledge and wisdom can help us to understand the changes associated with climate change that are occurring today and to enable adaptation.

Although Inuit now live in different circumstances (e.g., in permanent settlements), TEK continues to be important in enabling flexibility and innovation in hunting, hazard avoidance, and emergency preparedness, especially under changing climatic conditions. The success of Inuit in the Arctic has long been associated with their ability to be flexible and innovative in their use of the environment and resources. Inuit work with unpredictability; adapt their seasonal cycles to hunt what is available when it is available; and rely on learned experiences, oral traditions, and group memory of past situations to respond to fluctuations in the environment and extreme events. Food sharing and intercommunity trade continue to be important strategies for addressing differences in food availability and nourishing a culture of self-worth, independence, and reciprocity.

Several studies and major international climate change reports (IPCC, 2007, 2010; UNFCC, 2010) have identified the importance of TEK in adaptation; however, its important role is not recognized in most adaptation policy processes. Policymaker discourses are often at odds with local narratives about maintaining livelihoods and give limited weight to the role that TEK can play in adaptation and minimizing risk. Climate change policy in Indigenous regions tends to focus on addressing the risks of climate change directly, rather than building on existing knowledge and practice of adaptation. In northern Canada, climate change adaptation needs to evolve from the identification and description of climate change risks to support practical adaptation entry points, including the transmission of TEK (Pearce et al., 2011a).

This paper contributes to a growing body of scholarship on the role of TEK in adaptation to environmental change. Specifically, it complements the extensive work being carried out on the vulnerability of Inuit subsistence hunting to climate change by conceptualizing the relationship between TEK and adaptation. TEK is a reservoir of accumulated knowledge of changing conditions and experiences of adaptation that Inuit may draw on in responding to climatic risks; it increases their adaptive capacity and reduces vulnerability. Although the role of TEK in adaptation is simplified here, it is hoped that conceptualizing the relationships between TEK and adaptation using vulnerability concepts and terms will make it easier for this information to enter climate change adaptation policy discourse.

\section{ACKNOWLEDGEMENTS}

This paper builds on data and ideas generated in partnership with Inuit in the Canadian Arctic. The generosity, friendships and knowledge shared by the people of Ulukhaktok, Arctic Bay, Igloolik, Iqaluit, and Rigolet are gratefully acknowledged. Thank you to Dr. Christopher Furgal, Dr. Peter Collings, Frank Duerden, Dr. Benjamin Bradshaw, and members of the Global Environmental Change Group in the Department of Geography at the University of Guelph and the Climate Change Adaptation Research Group in the Department of Geography at McGill University for intellectual input. Thank you to Vicky O'Rourke for design work on figures. A special thank you to Harold Wright, Adam Kudlak, Roland Notaina, Jerry Sr. Akoakhion, Jack Kataoyak, Ross Klengenberg, and Wallace Joss for intellectual input. Jimmy Kudlak, Mel Pretty, Jimmy and Nora Memogana, and Wilma Memogana, thank you; you are remembered and missed. The research that contributed to the development of this paper was made possible through support from ArcticNet, the International Polar Year CAVIAR project, SSHRC, a SSHRC Vanier Doctoral Scholarship, and the CIHR IK-ADAPT (Inuit Knowledge for Adapting to the Health Effects of Climate Change) project. 


\section{REFERENCES}

Adger, W.N. 2000. Social and ecological resilience: Are they related? Progress in Human Geography 24(3):347-364. http://dx.doi.org/10.1191/030913200701540465

. 2006. Vulnerability. Global Environmental Change 16(3):268-281.

http://dx.doi.org/10.1016/j.gloenvcha.2006.02.006

Andrachuk, M., and Smit, B. 2012. Community-based vulnerability assessment of Tuktoyaktuk, NWT, Canada to environmental and socio-economic changes. Regional Environmental Change 12(4):867-885.

http://dx.doi.org/10.1007/s10113-012-0299-0

Aporta, C. 2002. Life on the ice: Understanding the codes of a changing environment. Polar Record 38(207):341 - 354. http://dx.doi.org/10.1017/S0032247400018039

- 2011. Shifting perspectives on shifting ice: Documenting and representing Inuit use of the sea ice. The Canadian Geographer 55(1):6-19.

http://dx.doi.org/10.1111/j.1541-0064.2010.00340.x

Aporta, C., and Higgs, E. 2005. Satellite culture: Global positioning systems, Inuit wayfinding, and the need for a new account of technology. Current Anthropology 46(5):729-753. http://dx.doi.org/10.1086/432651

Balikci, A. 1968. The Netsilik Eskimos: Adaptive processes. In: Lee, R.B., and Devore, I., eds. Man the hunter. Chicago: Aldine Publishing Company. 78-82.

Barnhardt, R., and Kawagley, A.O. 2005. Indigenous knowledge systems and Alaska Native ways of knowing. Anthropology \& Education Quarterly 36(1):8-23.

http://dx.doi.org/10.1525/aeq.2005.36.1.008

Barry, R.G., Armstrong, R., Callaghan, T., Cherry, J., Gearheard, S., Nolin, A., Russell, D., and Zöckler, C. 2007. Chapter 4: Snow. In: Global outlook for ice \& snow. Nairobi: United Nations Environment Programme. 40-62.

Beckford, C., and Barker, D. 2007. The role and value of local knowledge in Jamaican agriculture: Adaptation and change in small-scale farming. The Geographical Journal 173(2):118-128. http://dx.doi.org/10.1111/j.1475-4959.2007.00238.x

Berkes, F. 1999. Sacred ecology: Traditional ecological knowledge and resource management. Philadelphia: Taylor \& Francis.

Berkes, F., and Jolly, D. 2002. Adapting to climate change: Social-ecological resilience in a Canadian Western Arctic Community. Conservation Ecology 5(2): 18.

http://www.consecol.org/vol5/iss2/art18/

Berkes, F., Folke, C., and Gadgil, M. 1995. Traditional ecological knowledge, biodiversity, resilience, and sustainability. In: Perrings, C.A., Mahler, K.-G., Folke, C., Holling, C.S., and Jansson, B.-O., eds. Biodiversity conservation: Problems and policies. Dordrecht, The Netherlands: Kluwer Academic. $281-299$.

http://dx.doi.org/10.1007/978-94-011-0277-3_15
Berrang-Ford, L., Dingle, K., Ford, J.D., Lee, C., Lwasa, S., Namanya, D.B., Henderson, J., Llanos, A., Carcamo, C., and Edge, V. 2012. Vulnerability of Indigenous health to climate change: A case study of Uganda's Batwa Pygmies. Social Science \& Medicine 75(6):1067- 1077.

http://dx.doi.org/10.1016/j.socscimed.2012.04.016

Boas, F. 1888. The Central Eskimo. Sixth Annual Report of the Bureau of American Ethnology for the years 1884-1885. Washington, D.C.: Government Printing Office. 399-669.

Bravo, M.T. 2009. Voices from the sea ice: The reception of climate impact narratives. Journal of Historical Geography 35(2):256-278.

http://dx.doi.org/10.1016/j.jhg.2008.09.007

Brooks, N. 2003. Vulnerability, risk and adaptation: A conceptual framework. Working Paper No. 38. Norwich: Tyndall Centre for Climate Change Research. $20 \mathrm{p}$.

Budreau, D., and McBean, G. 2007. Climate change, adaptive capacity and policy direction in the Canadian North: Can we learn anything from the collapse of the east coast cod fishery? Mitigation and Adaptation Strategies for Global Change 12(7):1305-1320.

http://dx.doi.org/10.1007/s11027-006-9053-6

Chapin, F.S., Hoel, M., Carpenter, S.R., Lubchenco, J., Walker, B., Callaghan, T.V., Folke, C., et al. 2006. Building resilience and adaptation to manage Arctic change. Ambio 35(4):198-202. http://dx.doi.org/10.1579/0044-7447(2006)35[198:BRAATM]2 .0.CO;2

Collings, P. 1997. Subsistence hunting and wildlife management in the Central Canadian Arctic. Arctic Anthropology 34(1):41-56.

http://www.jstor.org/stable/40316423

- 2011. Economic strategies, community, and food networks in Ulukhaktok, Northwest Territories, Canada. Arctic 64(2):207-219.

http://dx.doi.org/10.14430/arctic4100

Condon, R.G. 1996. The northern Copper Inuit: A history. Toronto: University of Toronto Press.

Condon, R.G., Collings, P., and Wenzel, G. 1995. The best part of life: Subsistence hunting, ethnicity, and economic adaptation among young adult Inuit males. Arctic 48(1):31 - 46.

http://dx.doi.org/10.14430/arctic1222

Cruikshank, J. 1998. The social life of stories: Narrative and knowledge in the Yukon Territory. Vancouver: UBC Press.

Cunsolo Willox, A., Harper, S.L., Edge, V.L., Landman, K., Houle, K., Ford, J.D., and the Rigolet Inuit Community Government. 2013. The land enriches the soul: On climatic and environmental change, affect, and emotional health and well-being in Rigolet, Nunatsiavut, Canada. Emotion, Space and Society 6:14-24. http://dx.doi.org/10.1016/j.emospa.2011.08.005

Cutter, S.L. 1996. Vulnerability to environmental hazards. Progress in Human Geography 20(4):529-539. http://dx.doi.org/10.1177/030913259602000407

Folke, C. 2006. Resilience: The emergence of a perspective for social-ecological systems analyses. Global Environmental Change 16(3):253-267.

http://dx.doi.org/10.1016/j.gloenvcha.2006.04.002 
Ford, J.D., and Pearce T. 2012. Climate change vulnerability and adaptation research focusing on the Inuit subsistence sector in Canada: Directions for future research. The Canadian Geographer 56(2):275-287. http://dx.doi.org/10.1111/j.1541-0064.2012.00418.x

Ford, J.D., and Smit, B. 2004. A framework for assessing the vulnerability of communities in the Canadian Arctic to risks associated with climate change. Arctic 57(4):389-400. http://dx.doi.org/10.14430/arctic516

Ford, J.D., Smit, B., Wandel, J., and MacDonald, J. 2006a. Vulnerability to climate change in Igloolik, Nunavut: What we can learn from the past and present. Polar Record 42(2):127-138. http://dx.doi.org/10.1017/S0032247406005122

Ford, J.D., Smit, B., and Wandel, J. 2006b. Vulnerability to climate change in the Arctic: A case study from Arctic Bay, Canada. Global Environmental Change 16(2):145-160. http://dx.doi.org/10.1016/j.gloenvcha.2005.11.007

Ford, J.D., Pearce, T., Gilligan, J., Smit, B., and Oakes, J. 2008a. Climate change and hazards associated with ice use in northern Canada. Arctic, Antarctic, and Alpine Research 40(4):647-659. http://dx.doi.org/10.1657/1523-0430(07-040)[FORD]2.0.CO;2

Ford, J.D., Smit, B., Wandel, J., Allurut, M., Shappa, K., Ittusarjuat, H., and Qrunnut, K. 2008b. Climate change in the Arctic: Current and future vulnerability in two Inuit communities in Canada. The Geographical Journal 174(1):45-62. http://dx.doi.org/10.1111/j.1475-4959.2007.00249.x

Ford, J.D., Gough, W.A., Laidler, G.J., MacDonald, J., Irngaut, C., and Qrunnut, K. 2009. Sea ice, climate change, and community vulnerability in northern Foxe Basin, Canada. Climate Research 38(2):137-154. http://dx.doi.org/10.3354/cr00777

Ford, J.D., Pearce, T., Duerden, F., Furgal, C., and Smit. B. 2010. Climate change policy responses for Canada's Inuit population: The importance of and opportunities for adaptation. Global Environmental Change 20(1):177-191. http://dx.doi.org/10.1016/j.gloenvcha.2009.10.008

Ford, J.D., Bolton, K.C., Shirley, J., Pearce, T., Tremblay, M., and Westlake, M. 2012. Research on the human dimensions of climate change research in Nunavut, Nunavik, and Nunatsiavut: A literature review and gap analysis. Arctic 65(3):289-304. http://dx.doi.org/10.14430/arctic4217

Ford, J.D., McDowell, G., Shirley, J., Pitre, M., Siewierski, R., Gough, W., Duerden, F., Pearce, T., Adams, P., and Statham, S. 2013. The dynamic multiscale nature of climate change vulnerability: An Inuit harvesting example. Annals of the Association of American Geographers 103(5):1193-1211. http://dx.doi.org/10.1080/00045608.2013.776880

Fox, S. 2004. When the weather is uggianaqtuq: Linking Inuit and scientific observations of recent environmental change in Nunavut, Canada. PhD thesis, Department of Geography, University of Colorado at Boulder.

Frankland, R., Hardwick, L., and Watkin, S. 2012. Climate change adaptation in a small Pacific island nation. Proceedings of the ICE - Civil Engineering 165(6):46-51.

http://dx.doi.org/10.1680/cien.11.00054
Freeman, M.M. 1996. Identity, health and social order. In: Foller, M.-L., and Hansson, L.O., eds. Human ecology and health: Adaptation to a changing world. Gothenburg, Sweden: Gothenburg University. 57-71.

Furgal, C., and Prowse, T.D. 2008. Northern Canada. In: Lemmen, D.S., Warren, F.J., Lacroix, J., and Bush, E., eds. From impacts to adaptation: Canada in a changing climate 2007. Ottawa: Government of Canada. 57-118.

Furgal, C., and Seguin, J. 2006. Climate change, health, and vulnerability in Canadian northern Aboriginal communities. Environmental Health Perspectives 114(12):1964-1970. http://dx.doi.org/10.1289/ehp.8433

Gadjil, M., Berkes, F., and Folke, C. 1993. Indigenous knowledge for biodiversity conservation. Ambio 22(2/3):151 - 156.

Gearheard, S., Matumeak, W., Angutikjuaq, I., Maslanik, J., Huntington, H.P., Leavitt, J., Matumeak Kagak, D., Tigullaraq, G., and Barry, R.G. 2006. "It's not that simple": A collaborative comparison of sea ice environments, their uses, observed changes, and adaptations in Barrow, Alaska, USA, and Clyde River, Nunavut, Canada. Ambio 35(4):203-211. http://dx.doi.org/10.1579/0044-7447(2006)35[203:INTSAC]2.0 $\mathrm{CO} ; 2$

Gearheard, S., Pocernich, M., Stewart, R., Sanguya, J., and Huntington, H.P. 2010. Linking Inuit knowledge and meteorological station observations to understand changing wind patterns at Clyde River, Nunavut. Climatic Change 100(2):267-294. http://dx.doi.org/10.1007/s10584-009-9587-1

GNWT (Government of the Northwest Territories). Policy 53.03: Traditional knowledge. Yellowknife: GNWT. http://www.enr.gov.nt.ca/sites/default/files/documents/53_03_ traditional_knowledge_policy.pdf

Heyes, S.A. 2011. Cracks in the knowledge: Sea ice terms in Kangiqsualujjuaq, Nunavik. The Canadian Geographer 55(1):69-90. http://dx.doi.org/10.1111/j.1541-0064.2010.00346.x

Huntington, H.P. 1998. Observations on the utility of the semidirective interview for documenting traditional ecological knowledge. Arctic 51(3):237-242.

http://dx.doi.org/10.14430/arctic1065

Ingold, T. 2000. The perception of the environment: Essays on livelihood, dwelling and skill. London and New York: Routledge. http://dx.doi.org/10.4324/9780203466025

IPCC (Intergovernmental Panel on Climate Change). 2007. Summary for policymakers. In: Solomon, S., Qin, D., Manning, M., Chen, Z., Marquis, M., Averyt, K.B., Tignor, M., and Miller, H.L., eds. Climate change 2007: The physical science basis. Contribution of Working Group I to the Fourth Assessment Report of the Intergovernmental Panel on Climate Change. New York: Cambridge University Press.

2010. Review of the IPCC processes and procedures: Report by the Interacademy Council. In: Report of the $32^{\text {nd }}$ session of the IPCC. 11-14 October 2010, Busan, Republic of Korea. 
Jenness, D. 1917. The Copper Eskimo. The Geographical Review 4(2):81-91.

http://www.jstor.org/stable/207288

Krupnik, I. 1993. Arctic adaptations: Native whalers and reindeer herders of northern Eurasia. Hanover, New Hampshire: University Press of New England. 355 p.

. 2002. Watching ice and weather our way: Some lessons from Yupik observations of sea ice and weather on St. Lawrence Island, Alaska. In: Krupnik, I., and Jolly, D., eds. The Earth is faster now: Indigenous observations of Arctic environmental change. Fairbanks, Alaska: Arctic Research Consortium of the United States. 156-197.

Krupnik, I., and Jolly, D., eds. 2002. The Earth is faster now: Indigenous observations of Arctic environmental change. Fairbanks, Alaska: Arctic Research Consortium of the United States.

Laidler, G.J., and Elee, P. 2008. Human geographies of sea ice: Freeze/thaw processes around Cape Dorset, Nunavut, Canada. Polar Record 44(1):51 - 76. http://dx.doi.org/10.1017/S0032247407007061

Laidler, G.J., and Ikummaq, T. 2008. Human geographies of sea ice: Freeze/thaw processes around Igloolik, Nunavut, Canada. Polar Record 44(2):127-153.

http://dx.doi.org/10.1017/S0032247407007152

Laidler, G.J., Ford, J.D., Gough, W.A., Ikummaq, T., Gagnon, A.S., Kowal, S., Qrunnut, K., and Irngaut, C. 2009. Travelling and hunting in a changing Arctic: Assessing Inuit vulnerability to sea ice change in Igloolik, Nunavut. Climatic Change 94 (3-4):363-397.

http://dx.doi.org/10.1007/s10584-008-9512-z

Lewis, H.T. 1989. Ecological and technical knowledge of fire: Aborigines versus park managers in northern Australia. American Anthropologist 91:940-961.

Nakashima, D.J., Galloway McLean, K., Thulstrup, H.D., Ramos Castillo, A., and Rubis, J.T. 2012. Weathering uncertainty: Traditional knowledge for climate change assessment and adaptation. Paris: UNESCO; Darwin: United Nations University. 120 p.

Nelson, R.K. 1969. Hunters of the northern ice. Chicago, Illinois: University of Chicago Press.

Nickels, S., Furgal, C., Buell, M., and Moquin, H. 2006. Unikkaaqatigiit-Putting the human face on climate change: Perspectives from Inuit in Canada. Ottawa: Joint Publication of Inuit Tapiriit Kanatami, Nasivvik Centre for Inuit Health and Changing Environments at Université Laval and the Ajunnginiq Centre at the National Aboriginal Health Organization.

Noongwook, G., The Native Village of Savoonga, The Native Village of Gambell, Huntington, H.P., and George, J.C. 2007. Traditional knowledge of the bowhead whale (Balaena mysticetus) around St. Lawrence Island, Alaska. Arctic 60(1):47-54.

http://dx.doi.org/10.14430/arctic264
Nyong, A., Adesina, F., and Osman Elasha, B. 2007. The value of Indigenous knowledge in climate change mitigation and adaptation strategies in the African Sahel. Mitigation and Adaptation Strategies for Global Change 12(5):787-797.

http://dx.doi.org/10.1007/s11027-007-9099-0

Ohmagari, K., and Berkes, F. 1997. Transmission of Indigenous knowledge and bush skills among the Western James Bay Cree women of subarctic Canada. Human Ecology 25(2):197-222. http://dx.doi.org/10.1023/A:1021922105740

Oskal, A., Turi, J.M., Mathiesen, S.D., and Burgess, P., eds. 2009. EALÁT. Reindeer herders' voice: Reindeer herding, traditional knowledge and adaptation to climate change and loss of grazing land. Kautokeino, Norway: International Centre for Reindeer Husbandry. 135 p.

Parrotta, J.A., and Trosper, R.L., eds. 2012. Traditional forestrelated knowledge: Sustaining communities, ecosystems and biocultural diversity. World Forest Series, Vol. 12. Dordrecht, The Netherlands: Springer. $621 \mathrm{p}$. http://dx.doi.org/10.1007/978-94-007-2144-9

Pearce, T., and Smit, B. 2013. Vulnerability and adaptation to climate change in the Arctic. In: Seastedt, T.R., and Suding, K.N., eds. Climate vulnerability: Understanding and addressing threats to essential resources, Vol. 4: Vulnerability of ecosystems to climate. Amsterdam: Elsevier. Section 4.23.

Pearce, T., Smit, B., Duerden, F., Ford, J.D., Goose, A., and Kataoyak, F. 2010a. Inuit vulnerability and adaptive capacity to climate change in Ulukhaktok, Northwest Territories, Canada. Polar Record 46(2):157-177. http://dx.doi.org/10.1017/S0032247409008602

Pearce, T., Notaina, R., Wright, H., Kudlak, A., Ford, J., and Smit, B. 2010b. Transmission of environmental knowledge and land skills in adaptation planning for climate change in the Arctic. Meridian (Spring/Summer):6-11.

Pearce, T., Ford, J.D., Duerden, F., Smit, B., Andrachuk, M., Berrang-Ford, L., and Smith, T. 2011a. Advancing adaptation planning for climate change in the Inuvialuit Settlement Region (ISR): A review and critique. Regional Environmental Change 11(1):1-17. http://dx.doi.org/10.1007/s10113-010-0126-4

Pearce, T., Wright, H., Notaina, R., Kudlak, A., Smit, B., Ford, J.D., and Furgal, C. 2011b. Transmission of environmental knowledge and land skills among Inuit men in Ulukhaktok, Northwest Territories, Canada. Human Ecology 39(3):271 - 288. http://dx.doi.org/10.1007/s10745-011-9403-1

Peloquin, C., and Berkes, F. 2009. Local knowledge, subsistence harvests, and social-ecological complexity in James Bay. Human Ecology 37(5):533-545.

http://dx.doi.org/10.1007/s10745-009-9255-0

Prno, J., Bradshaw, B., Wandel, J., Pearce, T., Smit, B., and Tozer, L. 2011. Community vulnerability to climate change in the context of other exposure-sensitivities in Kugluktuk, Nunavut. Polar Research 30, 7363. http://dx.doi.org/10.3402/polar.v30i0.7363

Rakshit, A., and Bhowmick, M.K. 2012. Unrealized potential of traditional knowledge in combating climate change. SATSA Mukhapatra Annual Technical Issue 16:68-73. 
Sabo, G. 1991. Long-term adaptations among Arctic huntergatherers: A case study from southern Baffin Island. New York: Garland Publishing.

Smit, B., and Wandel, J. 2006. Adaptation, adaptive capacity and vulnerability. Global Environmental Change 16(3):282-292. http://dx.doi.org/10.1016/j.gloenvcha.2006.03.008

Smit, B., Burton, I., Klein, R.J.T., and Wandel, J. 2000. An anatomy of adaptation to climate change and variability. Climatic Change 45(1):223-251. http://dx.doi.org/10.1023/A:1005661622966

Stefansson, V. 1922. The friendly Arctic: The story of five years in polar regions. New York: Macmillan.

Stevenson, M.G. 1996. Indigenous knowledge in environmental assessment. Arctic 49(3):278-291. http://dx.doi.org/10.14430/arctic1203

Takano, T. 2005. Connections with the land: Land-skills courses in Igloolik, Nunavut. Ethnography 6(4):463-486. http://dx.doi.org/10.1177/1466138105062472

Taylor, W.E., Jr. 1966. An archaeological perspective on Eskimo economy. Antiquity 40(158):114-120. http://dx.doi.org/10.1017/S0003598X00032282

Tremblay, M., Furgal, C., Larrivée, C., Annanack, T., Tookalook, P., Qiisik, M., Angiyou, E., Swappie, N., Savard, J.-P., and Barrett, M. 2008. Climate change in northern Quebec: Adaptation strategies from community-based research. Arctic 61(Suppl. 1):27-34. http://dx.doi.org/10.14430/arctic99

Turner, B.L., Kasperson, R.E., Matson, P.A., McCarthy, J.J., Corell, R.W., Christensen, L., Eckley, N., et al. 2003. A framework for vulnerability analysis in sustainability science. Proceedings of the National Academy of Sciences 100(14):8074-8079.

http://dx.doi.org/10.1073/pnas.1231335100
Turner, N.J., and Clifton, H. 2009. "It's so different today": Climate change and Indigenous lifeways in British Columbia, Canada. Global Environmental Change 19(2):180-190. http://dx.doi.org/10.1016/j.gloenvcha.2009.01.005

UNFCCC (United Nations Framework Convention on Climate Change). 2010. Report of the Conference of the Parties on its 16th session (FCCC/CP/2010/7/Add.1), Cancun, Mexico 29 November - 10 December 2010. Geneva, Switzerland: United Nations.

http://unfccc.int/resource/docs/2010/cop16/eng/07a01.pdf

Usher, P.J. 2000. Traditional ecological knowledge in environmental assessment and management. Arctic 53(2):183-193. http://dx.doi.org/10.14430/arctic849

Vincent, K. 2007. Uncertainty in adaptive capacity and the importance of scale. Global Environmental Change 17(1):12-24.

http://dx.doi.org/10.1016/j.gloenvcha.2006.11.009

Wenzel, G. 1987. "I was once independent": The southern seal protest and Inuit. Anthropologica 29(2):195-210. http://dx.doi.org/10.2307/25605231

—. 1991. Animal rights, human rights: Ecology, economy and ideology in the Canadian Arctic. Toronto: University of Toronto Press.

—. 1999. Traditional ecological knowledge and Inuit: Reflections on TEK research and ethics. Arctic 52(2):113-124. http://dx.doi.org/10.14430/arctic916

2. 2009. Canadian Inuit subsistence and ecological instability - if the climate changes, must the Inuit? Polar Research 28(1):89-99.

http://dx.doi.org/10.1111/j.1751-8369.2009.00098.x 